\begin{tabular}{ll}
\hline \hline MINING AND METALLURGY INSTITUTE BOR & ISSN: 2334-8836 \\
& UDK: 622 \\
\hline \hline
\end{tabular}

\title{
STRIPPING DELAY ANALYSIS IN RELATION TO DESIGNED LONG-TERM PLAN OF EXCAVATION AT THE OPEN PIT VELIKI KRIVELJ
}

\begin{abstract}
Analysis of mining operations after two and a half years of work by the Project DMD - from the 2011, made in software for strategic planning - Whittle $F x$, indicates a deviation from the planned dynamics, and problem of achieving the design planned production of 10.6 million tons of ore in 2014. It also points out the reduction of annual average copper content in the ore, increased overburden ratio in the next period regarding to the planned, thus reducing the economic effects of excavation as a consequence of the previous delay in stripping. Consequently, these facts challenging the planned copper recovery from the ore in the flotation process and planned concentrate quality. Altogether acts as a negative impact on the economic effects of business.

Although the necessity of finding the short-term solutions in situations where delay in stripping is present as well as danger in discontinuity of ore excavation, a common practice is to resolve the problem deviating from design solutions, which is basically just a postpone effect of delay.

Until now, the delay in stripping has reached the figure of 24,280,718 $t$.

Keywords: waste rock (overburden), cut-off grade, open pit, Whittle Fx, dynamics
\end{abstract}

\section{INTRODUCTION}

The basic modern approach to design of open pit mining is to identify a contour of open pit based on the criteria of optimal profit. The input techno economic parameters allow, using Whittle software Fx, a strategic production planning with optimal economic effects, i.e. a selection of open pit contour per criterion of optimal profit.

This design principle was also applied in development the Additional Mining Design of Copper Ore Excavation and Processing of the Ore Deposit Veliki Krivelj for Capacity of $10.6 \times 10^{6}$ tons of Wet Ore per Year (MMI Bor, submitted to the Investor for use in March 2011).
The reason that this project development was the increase of production capacity from 8.5 to 10.6 million tons of ore per year, but the deviation from excavation dynamics designed by DMD was caused in 2006 (for $8.5 \mathrm{Mt}$ ), and therefore a certain risk of loss in continuity of ore mining. Delay in stripping at that time was the result of, among other things, working with old and unreliable equipment at the open pit.

Analyzing the mining operations at the open pit Veliki Krivelj after only two and a half years of operation according to the new DMD for the capacity of $10.5 \mathrm{Mt}$, in the period when the modern equipment was

\footnotetext{
* Mining and Metallurgy Institute Bor
} 
bought - from drills through loading and haulage equipment and additional equipment - bulldozers, graders, tanks for watering of roads, etc., shows that delay in stripping has appeared again and thus deviation from designed solutions and parameters that guarantee the optimal profit, verified by technoeconomic analysis of design. This delay cannot be justified as the result of lack of equipment.

Appropriate departments, dealing with short-term production planning in RBB, the lack of stripped ore for planned annual production solve by shortening the project defined phases, what is the only solution at the given moment, but the solution that is not long-term justified and expensive. Such decisions directly affect the economic effects of mining, disrupt the designed ratio of overburden in the coming years (increasing it), disrupt the annual average copper content in the ore (reducing it), reducing the same reduce the revenues from copper and precious metals.

The only solution could be found out in compensation the residual amounts of waste rock, but with supplying the additional required funds to finance the excavation of additional amounts of waste rock, or just a compensation the amount of waste that can be financed out from profit with planned production of ore and waste rock.

The aim of this work is to emphasize the importance of achieving the planned dynamics of stripping or achieving the planned production parameters, determined by the Project. Each improvisation in planning in relation to the implementation project also requires the adequate comprehensive analysis of consequences that can be expected in the future period with defining the measuresthat have to be taken in order to annulment the negative impacts of delay. In case of deviation from designed dynamics and contours defined by the project, there is no longer a pit contour, selected by the criterion of optimal profit.

\section{ANALYSIS}

In further text, a designed excavation dynamics is given below per years in stages 1, 2, 3 and 4, with planned annual amounts: excavation, ore, waste, copper (in tons) and copper content in the ore (in percentages) and the ratio of overburden to ore, i.e. the overburden ratio (2.1), and then dynamics of excavation the remaining amounts of ore and overburden in the given phases of open pit per Project, after two and a half years of operation.

The first year of the new dynamics is actually the remaining 5 months of this year, with the corresponding amounts of excavation and ore, which is linked to the condition of work of $23^{\text {rd }}$ July of the current year.

As the primary analysis of excavation dynamics is given in this work, but not the PV and NPV, only copper without precious metals is exported from basic software in Whittle. Therefore, the conclusion will only show the economic effect on the basis of copper with long-term price of $6000 \mathrm{US} \$ / \mathrm{t}$ of cathode, and only as an indicator of the trend of economic effects.

The following table shows the planned long-term excavation dynamics per years from the Additional Mining Design of Copper Ore Excavation and Processing of the Ore Deposit Veliki Krivelj for Capacity of $10.6 \times 10^{6}$ tons of Wet Ore per Year (MMI Bor, March 2011). 
Table 1 Designed excavation dynamics by DMD from 2010

\begin{tabular}{|c|c|c|c|c|c|c|}
\hline & & & & & Units to & Grade \\
\hline & tonne & tonne & Waste & Strip & process & input \\
\hline Period & in place & input & tonne & ratio & $\mathrm{CU}$ & CU \\
\hline 2011 & $29,001,893$ & $8,601,683$ & $20,400,210$ & 2.37 & 21416 & 0.00249 \\
\hline 2012 & $31,005,938$ & $10,601,750$ & $20,404,188$ & 1.92 & 33180 & 0.00313 \\
\hline 2013(1) & $30,992,084$ & $10,602,612$ & $20,389,472$ & 1.92 & 31618 & 0.00298 \\
\hline 2014(2) & $30,884,755$ & $10,604,019$ & $20,280,736$ & 1.91 & 24309 & 0.00229 \\
\hline 2015(3) & $31,005,202$ & $10,600,998$ & $20,404,204$ & 1.92 & 27239 & 0.00257 \\
\hline 2016(4) & $31,020,278$ & $10,601,968$ & $20,418,310$ & 1.93 & 31801 & 0.003 \\
\hline 2017 (5) & $31,010,886$ & $10,601,762$ & $20,409,124$ & 1.93 & 31242 & 0.00295 \\
\hline 2018(6) & $31,000,513$ & $10,600,062$ & $20,400,451$ & 1.92 & 33964 & 0.0032 \\
\hline 2019(7) & $27,399,915$ & $10,606,131$ & $16,793,784$ & 1.58 & 33518 & 0.00316 \\
\hline 2020(8) & $21,999,033$ & $10,600,785$ & $11,398,248$ & 1.08 & 32757 & 0.00309 \\
\hline $2021 / 2025$ & $91,604,842$ & $53,124,566$ & $38,480,276$ & 0.72 & 163712 & 0.00308 \\
\hline $2026 / 2031$ & $59,153,144$ & $55,451,108$ & $3,702,036$ & 0.07 & 207968 & 0.00375 \\
\hline Ukupno & $446,078,483$ & $212,597,444$ & $233,481,039$ & 1.10 & 672723 & 0.00316 \\
\hline
\end{tabular}

\subsection{Analysis of excavation dynamics in designed phases (DMD 2011) after realized works 2011 - July 2013}

The excavation dynamics in stages 1 , 2, 3 and 4 was designed in the software Whittle Fx, after the data preparation in the basic software (Gemcom), i.e. export of geological block model of the deposit Veliki Krivelj with appropriate topography - a condition of work on $23^{\text {rd }}$ July 2013 (Figure 1). The study also includes the Pit List with designed stages of open pit and given condition of the field (Figure 2). The limits in Whittle are, in addition to surveying the condition of mining works and excavation amounts of 31 million tons, calculated as in the Project 10.6 Mt

of ore, something more than $20 \mathrm{Mt}$ of waste rock with a capacity of transport system for waste and disposal on truck landfill Todorov Potok and East landfill. The third limit is the annual ore processing capacity of flotation ore processing, with $\mathrm{Cu}$ cut-off grade in the ore, in this case $0: 15 \% \mathrm{Cu}$. Since the condition was used from the second half of July 2013, the limits for the first year of the new dynamics are proportionally taken to the annual capacity but for the remaining 5 months of the current year $(12,916,666 \mathrm{t}$ of excavation and 4,375 million $t$ of ore). 


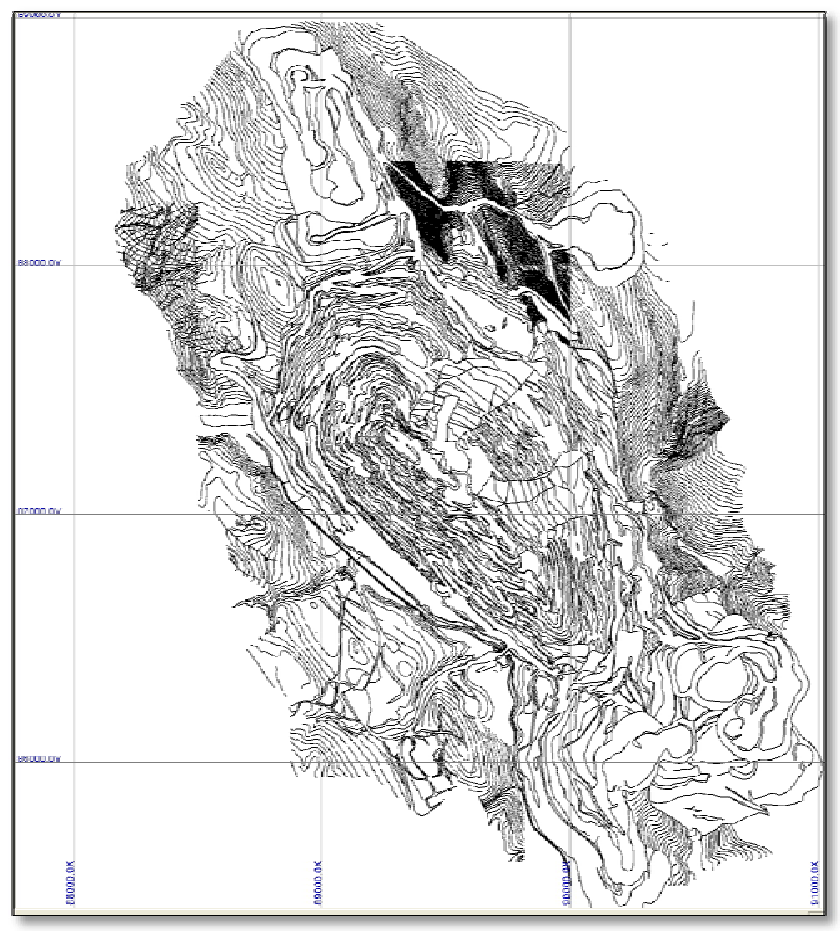

Figure 1 Condition of mining activities, July 2013, at the open pit Veliki Krivelj

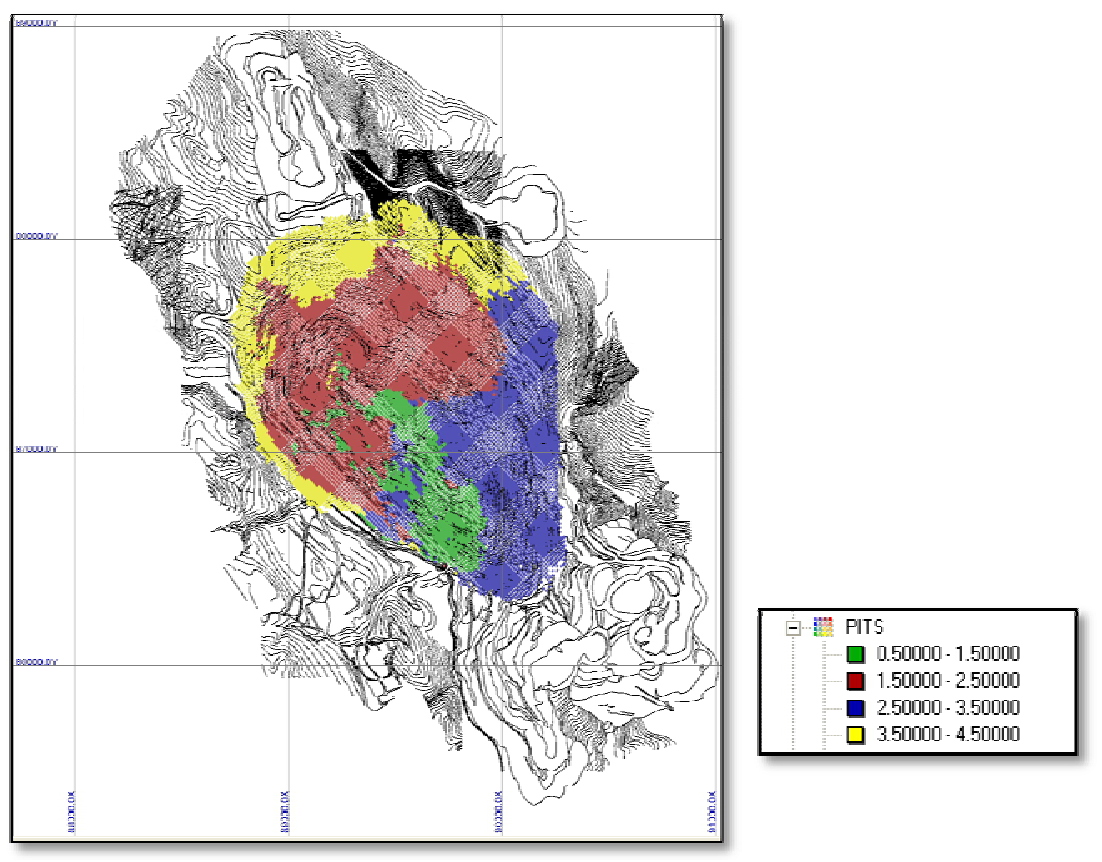

Figure 2 Pit list of the open pit Veliki Krivelj with legend of stage 1 (0.5 - 1.5), stage $2(1.5-2.5)$, stage $3(2.5-3.5)$, stage $4(3.5-4.5)$ 
The above limits are important due to the dynamics which is generated by software and shown in the follo- wing tables (Table 2 - cumulative dynamics and Table 3 - detailed dynamics per stages).

Table 2 Dynamics of excavation based on analysis with condition of activities, 23.07.2013.

\begin{tabular}{|c|c|c|c|c|c|c|c|}
\hline & & & & & Units to & Grade & \\
\hline & tonne & tonne & Waste & Strip & process & input & \\
\hline Period & In place & Input & tonne & ratio & $\mathrm{CU}$ & $\mathrm{CU}$ & \\
\hline $1(013)$ & $12,916,666$ & $4,733,404$ & $8,183,262$ & 1.73 & 14096 & 0.00298 & \\
\hline $2(014)$ & $31,000,000$ & $5,594,739$ & $25,405,261$ & 4.54 & 12553 & 0.00224 & \\
\hline $3(015)$ & $31,000,000$ & $10,595,226$ & $20,404,774$ & 1.93 & 24124 & 0.00228 & \\
\hline $4(016)$ & $31,000,000$ & $10,585,998$ & $20,414,002$ & 1.93 & 28117 & 0.00266 & \\
\hline $5(017)$ & $31,000,000$ & $10,595,816$ & $20,404,184$ & 1.93 & 32813 & 0.0031 & \\
\hline $6(018)$ & $31,000,000$ & $10,592,983$ & $20,407,017$ & 1.93 & 35140 & 0.00332 & \\
\hline $7(019)$ & $31,000,000$ & $10,598,912$ & $20,401,088$ & 1.92 & 37675 & 0.00355 & \\
\hline $8(020)$ & $31,000,000$ & $10,581,223$ & $20,418,777$ & 1.93 & 33399 & 0.00316 & IFGENDA \\
\hline $9(021)$ & $31,000,000$ & $10,599,457$ & $20,400,543$ & 1.92 & 25388 & 0.0024 & Bant \\
\hline 10 & $28,084,404$ & $10,599,999$ & $17,484,404$ & 1.65 & 25644 & 0.00242 & Good \\
\hline 11 & $17,073,507$ & $10,600,000$ & $6,473,507$ & 0.61 & 29095 & 0.00274 & P: $2021 / 2025$ \\
\hline 12 & $13,938,867$ & $10,600,000$ & $3,338,867$ & 0.31 & 30546 & 0.00288 & P: $2026 / 2031$ \\
\hline $13(025)$ & $12,145,076$ & $10,600,000$ & $1,545,076$ & 0.15 & 32578 & 0.00307 & PUSH-1 \\
\hline $14(026)$ & 11902505 & 10600000 & 1302505 & 0.12 & 34631 & 0.00327 & PUSH -3 \\
\hline 15 & 11202592 & 10600000 & 602592 & 0.06 & 35696 & 0.00337 & PUSH - 4 \\
\hline 16 & 11214552 & 10600000 & 614552 & 0.06 & 41155 & 0.00388 & Total \\
\hline 17 & 10880675 & 10600000 & 280675 & 0.03 & 40006 & 0.00377 & \\
\hline 18 & 11179814 & 10600000 & 579814 & 0.05 & 43214 & 0.00408 & \\
\hline 19(031) & 5940727 & 5401306 & 539421 & 0.1 & 21067 & 0.0039 & \\
\hline Ulaupno & $394,479,385$ & $185,279,063$ & $209,200,321$ & 1.13 & 576937 & 0.00311 & \\
\hline
\end{tabular}

The following table gives a detailed dynamics of excavation per designed stages of excavation at the open pit, which gives the excavation in periods/years.

From present tables, it is clear that the Project planned production of $10.6 \mathrm{Mt}$ is not realized in 2014 in designed stages (column 3, "tone input"). A solution will be again found out by "displacement" of stage limits, i.e. "reduction" of stages", what was discussed in introduction part of work. Reducing of stages practically means faster progress of the works in depth, leaving some parts of stage (push backs) unexcavated, mostly parts with prevailing rock waste or low metal content in the ore. 
Table 2 Detailed dynamics of excavation per stages according to the Analysis of 23.07.2013.

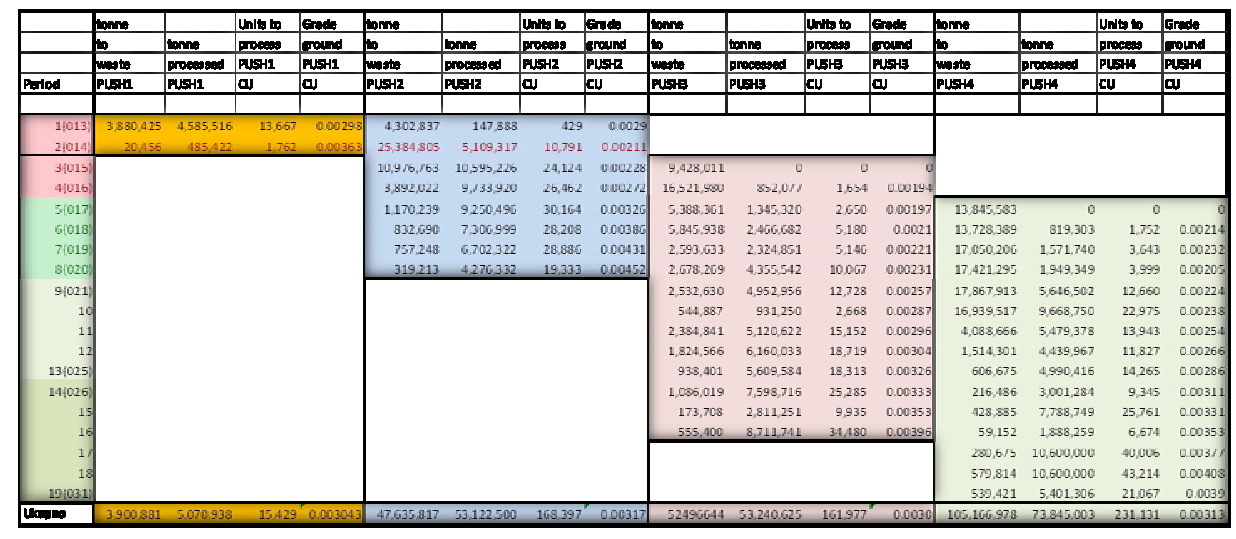

Graphic view of comparative parameters determined by Project and parameters, ob tained by Analysis, are shown below and apparently illustrate the considered proble

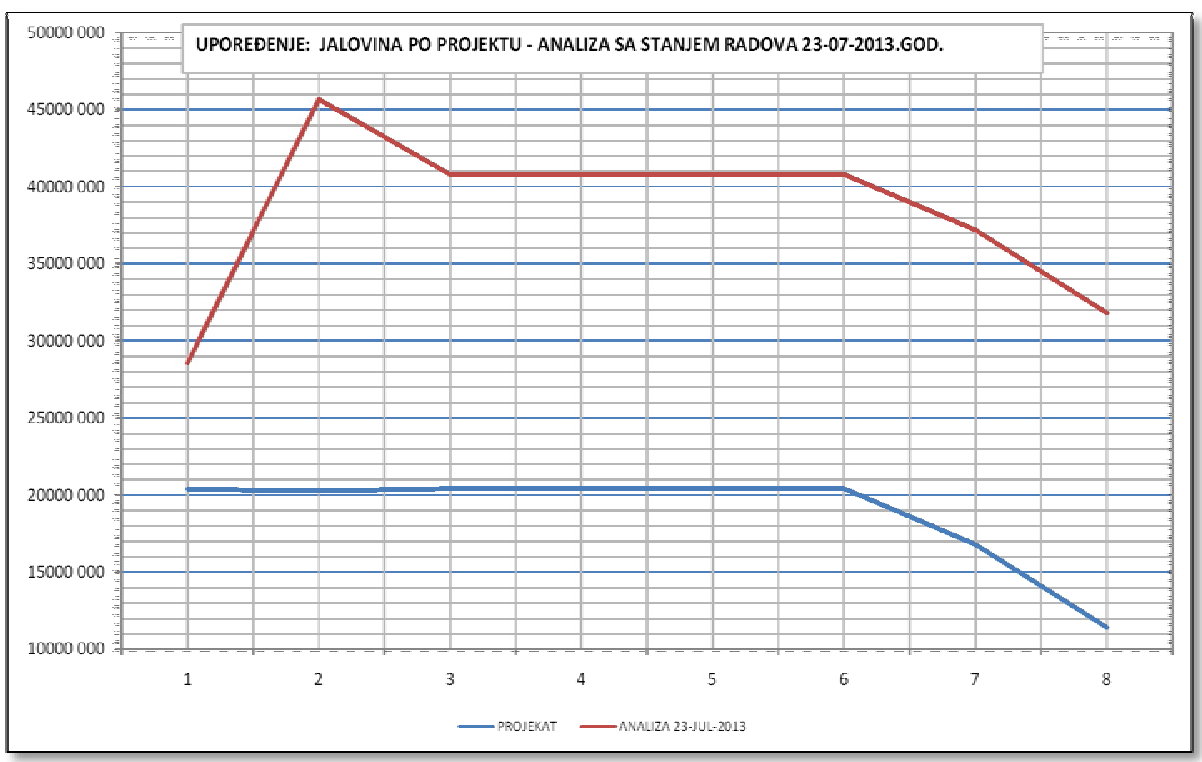

Graph 1 Ratio of the amount of WASTE per years in excavation dynamics according to the Project and generated new dynamics in the Analysis for the period until 2020

In 2013, continuity of excavation the planned ore amounts is conditionally retained (or it is possible to retain regarding the time of Analysis making), but thanks to a fact that in recent years the annual plans for ore excavation were not achieved, and thus partially offset the negative effect of delay in stripping. 


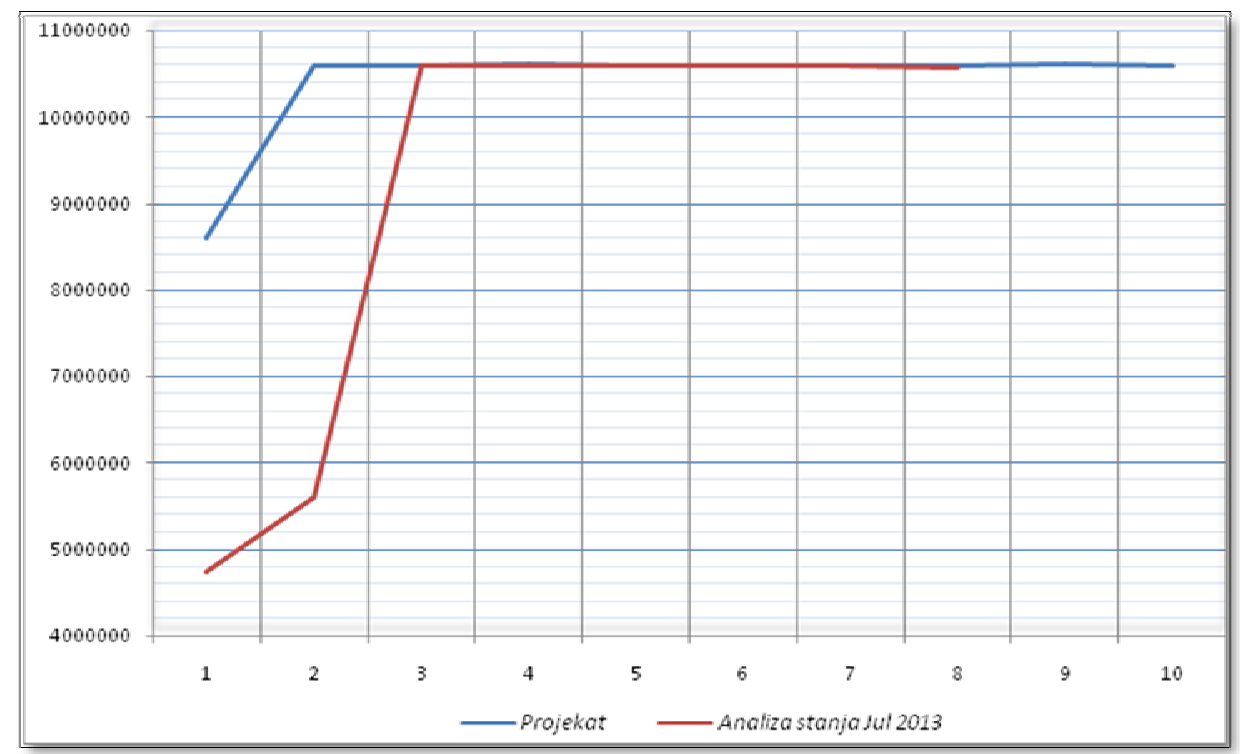

Graph 2 Ratio of ORE in excavation dynamics according to the Project and obtained dynamics in Analysis for the period until 2020

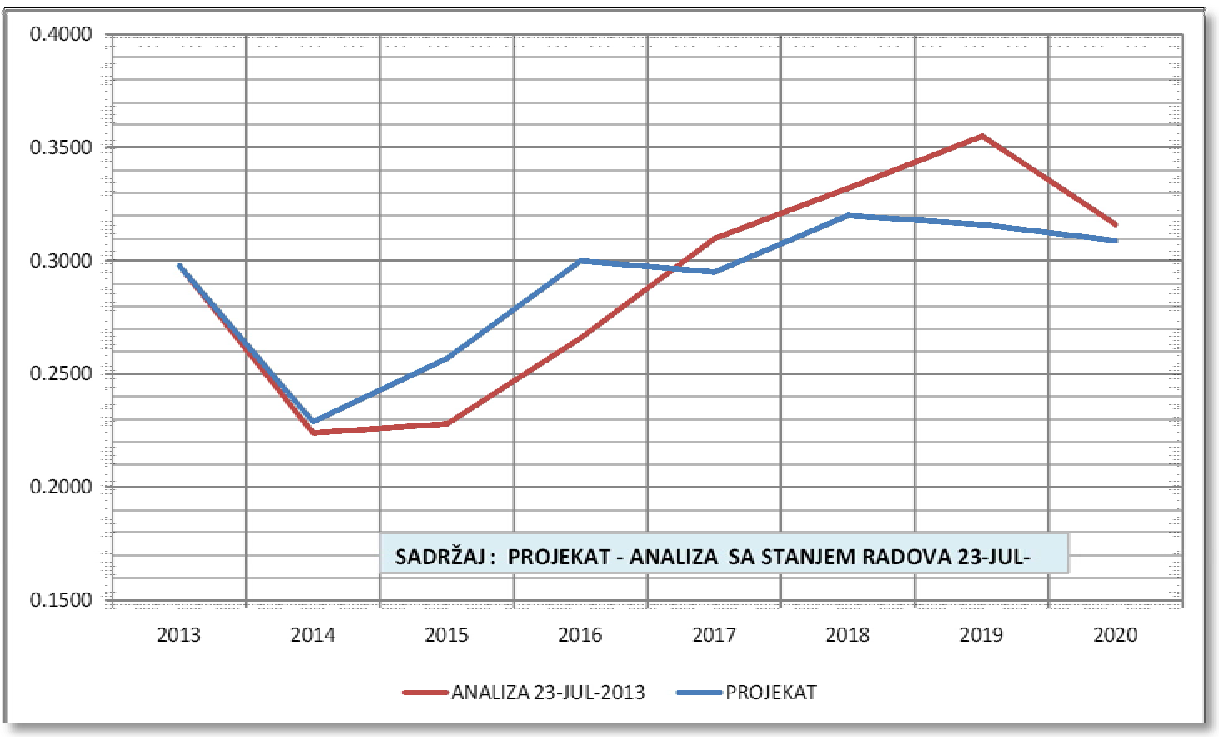

Graph 3 Ratio of CONTENT in excavation dynamics according to the Project and new dynamics in Analysis for the period until 2020 


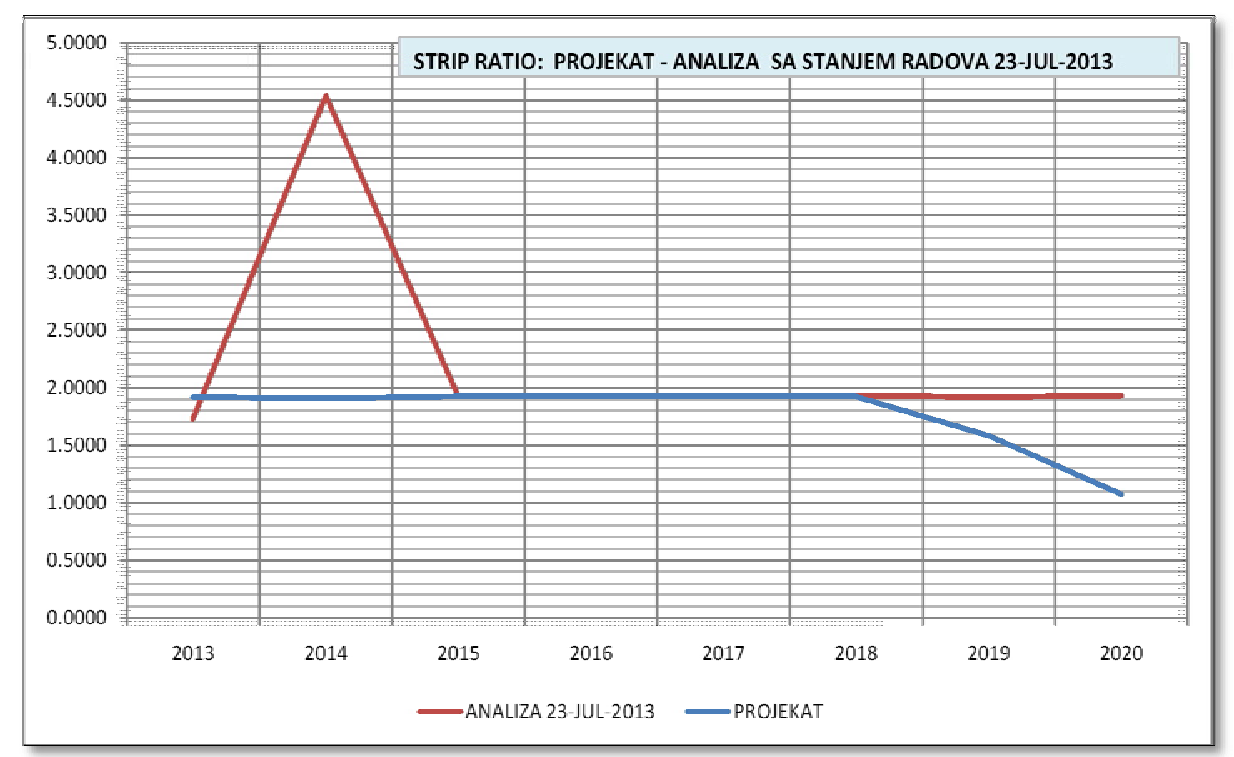

Graph 4 Comparison of STRIPPING RATION ( $t$ waste /t ore) in the Project and Analysis for the period until 2020

\section{CONCLUSION}

Deviation from designed solutions in the Project Additional Design of Copper Ore Excavation and Processing of the ore deposit Veliki Krivelj for Capacity of 10.6 $x 10^{6}$ tons of Wet Ore per Year (MMI Bor, March 2011), after 2.5 years of operation per the same, and due to delay in stripping that is $24,280,718$ tons, has resulted to the necessary "reducing" the designed stages of open pit with the aim of maintaining the continuity in the annual ore mining capacity of $10.6 \mathrm{Mt}$, as a choice of "the lesser evil of the two possible"

The consequences of such deviation are visible from the present tables and graphs, as well as the previous considerations and they are:

- Decrease Cu cut-off grade in the ore in the next period of 3 years - 2014, 2015, 2016 (tables and Graph 3);

- In the period 2014, 2015 and 2016, the stripping ratio is increased, i.e. it is necessary to operate with increased amount of waste (Table 2, Graph4);

- Although the primary goal was not a detailed economic analysis, wherefore the precious metals were not taken into account in importing the block model of deposit in Whittle, the Analysis and occurrence of loss are imposed as the result, only on the basis of copper (without precious metals) for the copper price of 6,000 US.\$ $t$, is about 26 Mil. US\$ (Table 5, output Whittle Fx.): 
Table 5 Financial effects (loss)

\begin{tabular}{|r|l|l|}
\hline & Open pit & Open pit \\
\hline & cashflow & cashflow \\
\hline Period & $\mathbf{\$}$ & \$ disc \\
\hline & & \\
\hline $1(013)$ & $12,473,839$ & $11,339,854$ \\
$2(014)$ & $-26,956,603$ & $-22,278,185$ \\
\hline
\end{tabular}

- Due to the reduced Cu content in the ore, there is the possibility of reduced flotation recovery and further negative impacts in the chain of processing, to the final product cathode. It is also with reduced input copper content in the ore to the order of just over $0.2 \% \mathrm{Cu}$, decreased ability to achieve the planned content of copper in concentrate in the flotation process. The influences on economic effects should be the subject of an analysis of technologists in the flotation plant and metallurgists in the smelter.

- Considering the investment in recent years at the open pit and flotation plant, and still present in the smelter, the world trends in such cases are to increase the profit in the first years after the period of investments in the shortest periods payback of investments. Regarding to the open pit, , this is accomplished in several ways. One way is, for example, the optimization of cut-off grade, then the use of stock pyle and blending of appropriate content, and similar. At the open pit Veliki Krivelj, the case is reversed. After invested large funds in the early years after investment (the analyzed period), there is a downward trend in profit.

- It is very obvious that this trend will continue if the works are not turned back to designed open pit contours by the waste compensation and under a condition that in the future period there would not been further deviations from the Project.

The all above supports the fact that realization of stripping dynamics, although the waste is expense, is in the open pit mining as important as the ore production. In the underground mining, this is the preparation stage - development of mining facilities for access to the ore body and creation the conditions for excavation. Delay in stripping increases the costs of total production in the next period and often leads to the loss of continuity in the ore excavation, if the annual plans do not include a compensation of residual tailings with suitable conditions from an aspect of funding the additional costs. Otherwise, it further implies the above mentioned effects, but the worst case - a break in the continuity of ore mining and investment stripping, and over the whole period the fixed costs exist and remain unchanged despite the fact that some parts of the plant will not be operational (flotation plant or some parts of flotation), what may lead into question further exploitation at the open pit (mine) by accumulation of losses. Such operation reduces the service life of the mine, thus the value of the mine (PV), or NPV.

Also, the attention has to be drawn to the question whether in the future, if described trend of development, it will be even possible generally in deposit to find 
out a contour of the open pit by any optimization, which would be economically viable without the period of investment stripping and cost-effective service life of exploitation.

\section{REFERENCES}

[1] Additional Mining Design of Copper Ore Excavation and Processing of the Ore Deposit Veliki Krivelj for Capacity of $10.6 \times 10^{6}$ tons of Wet Ore per Year, MMI Bor, March 2011 (in Serbian);
[2] Optimization of Mining Engineering Design in Mineral Valuation - Wells, Howard M. - Technical Papers, Mining engineering, Vol. 30, No. 12, December 1978, pp. 1676-1684;

[3] Cut-off Grade Optimisation, Whittle Consulting Pty Ltd, Strategic Mine Planning Specialists;

[4] Planning Operating Cutoff Grades, Arnold R. Pasieka Consulting Mining Engineer Hatch Associates Ltd. Toronto, Ontario, George V. Sotirow Special Projects Engineer MAPAO North Bay, Ontario. 


\begin{tabular}{ll}
\hline \hline INSTITUT ZA RUDARSTVO I METALURGIJU BOR & ISSN: 2334-8836 \\
& UDK: 622 \\
\hline \hline
\end{tabular}

Zoran Vaduvesković, Mile Bugarin ${ }^{*}$, Daniel Kržanovic ${ }^{*}$

\title{
ANALIZA KAŠNJENJA U RASKRIVANJU U ODNOSU NA PROJEKTOVANI DUGOROČNI PLAN OTKOPAVANJA NA POVRŠINSKOM KOPU VELIKI KRIVELJ
}

\begin{abstract}
Izvod
Analiza rudarskih radova nakon dve i po godine rada po Projektu DRP - u iz 2011. godine, urađene u softveru za strateško planiranje - Whittle Fx, ukazuje na odstupanje od planirane dinamike, $i$ na problem ostvarivanja projektom planirane proizvodnje od 10.600.000 t rude u 2014. godini. Takođe ukazuje i na smanjenje godišnjeg srednjeg sadržaja bakra u rudi, povećanje koeficijenta raskrivke u narednom periodu u odnosu na planirani, samim tim i smanjenje ekonomskih efekata otkopavanja, kao posledicu dosadašnjeg zakašnjenja u raskrivanju. Posledično, navedenim činjenicama se dovodi u pitanje planirano iskorišćenje bakra iz rude u procesu flotiranja i planirani kvalitet koncentrata. Sve ukupno deluje kao negativan uticaj na ekonomske efekte poslovanja.

Iako je neminovnost u nalaženju kratkoročnih rešenja u situacijama kada se kasni sa raskrivanjem $i$ preti opasnost prekida kontinuiteta u otkopavanju rude, učestala praksa je da se problem rešava odstupajući od projektnih rešenja, čime se u suštini samo odlažu posledice kašnjenja.

Do sada je kašnjenje na raskrivanju dostiglo cifru od 24.280.718 t.

Ključne reči: jalovina (raskrivka), ruda, granični sadržaj, površinski kop, Whittle Fx, dinamika otkopavanja.
\end{abstract}

\section{UVOD}

Osnovni savremeni pristup u projektovanju u površinskoj eksploataciji jeste da se odredi kontura površinskog kopa na osnovu kriterijuma optimalnog profita. Ulazni tehno ekonomski parametri omogućavaju, korišćenjem softvera Whittle Fx, strateško planiranje proizvodnje sa optimalnim ekonomskim efektima tj. izbor konture kopa po kriterijuти optimalnog profita.

Ovaj princip projektovanja je primenjen i prilikom izrade Dopunskog rudarskog projekta otkopavanja i prerade rude bakra u ležištu "Veliki Krivelj” za kapacitet 10,6 x $10^{6}$ tona vlažne rude godišnje, (IRM Bor, predat Investitoru na korišćenje marta 2011. godine).
Razlog zbog čega je navedeni projekat urađen bilo je povećanje kapaciteta proizvodnje sa 8,5 na 10,6 miliona tona rude godišnje, ali i nastalo odstupanje od dinamike otkopavanja projektovane DRPom iz 2006. godine (za 8,5 Mt), samim tim i vrlo izvesna opasnost pojave gubitka kontinuiteta u otkopavanju rude. Kašnjenje u raskrivanju je u to vreme bila posledica, pored ostalog, i rada sa starom i nepouzdanom opremom na kopu.

Analizom rudarskih radova na kopu Veliki Krivelj nakon samo dve i po godine rada po novom DRP-u za kapacitet od 10,5 Mt, u periodu kada je kupljena savremena oprema - od bušilica, preko utovarne i

\footnotetext{
* Institut za rudarstvo i metalurgiju Bor
} 
transportne opreme pa do prateće opreme buldozera, grejdera, cisterni za polivanje puteva i dr., pokazuje da se ponovo javlja kašnjenje na raskrivanju i samim tim odstupanje od projektovanih rešenja i parametara koji garantuju optimalan profit, verifikovan tehno-ekonomskom analizom projekta. Ovo se kašnjenje nikako ne može opravdati kao posledica nedostatka opreme.

Odgovarajuće službe koje se bave kratkoročnim planiranjem proizvodnje $u$ $\mathrm{RBB}$, problem nedostatka raskrivene rude za planiranu godišnju proizvodnju rešavaju skraćivanjem projektom definisanih faza, što je i jedino moguće rešenje $u$ datom momentu, ali rešenje koje dugoročno nije opravdano i koje je skupo. Takva rešenja direktno utiču na ekonomske efekte otkopavanja. Remete projektovani koeficijent raskrivke u narednim godinama (povećavajući ga), remete srednji godišnji sadržaj bakra u rudi (smanjujući ga), smanivanjem istog umanjuju prihode od $\mathrm{Cu}$ i plemenitih metala.

Jedno od rešenja se može tražiti $u$ nadoknadi zaostalih količina jalovine, ali sa obezbeđenjem dodatnih potrebnih finansijskih sredstava za finansiranje otkopavanja dodatne količine jalovine, ili pak samo nadoknada one količine jalovine koja se može finansirati iz dobiti sa planiranom proizvodnjom rude i jalovine.

Cilj ovog članka je ukazivanje na značaj ostvarivanja planirane dinamike raskrivanja, odnosno ostvarivanje planiranih parametara proizvodnje koji su Projektom određeni. Svaka improvizacija u planiranju $u$ odnosu na izvođački projekat zahteva $i$ odgovarajuću sveobuhvatnu analizu posledica koje se mogu očekivati u budućem periodu, sa definisanjem mera koje se moraju preduzeti u cilju anuliranja negativnih uticaja zakašnjenja. U slučaju odstupanja od projektovane dinamike $i$ kontura definisanih projektom, više se ne radi o konturi kopa izabranoj po kriterijumu optimalnog profita.

\section{ANALIZA}

U daljem tekstu je data projektovana dinamika otkopavanja po godinama u fazama otkopavanja 1, 2, 3 i 4 sa planiranim godišnjim količinama: iskopina, rude, jalovine, bakra (u tonama) i sadržajem bakra $\mathrm{u}$ rudi (u procentima) i odnosom jalovine $\mathrm{i}$ rude tj. koeficijentom raskrivke (2.1), a nakon toga dinamika otkopavanja preostalih količina rude $\mathrm{i}$ raskrivke $\mathrm{u}$ navedenim fazama kopa po Projektu, nakon dve i po godine rada.

Prva godina u novoj dinamici je u stvari 5 preostalih meseci ove godine, sa pripadajućim količinama iskopa i rude, koja se nadovezuje na stanje radova od 23. Jula tekuće godine.

Kako je u radu primarna analiza dinamike otkopavanja, ne i PV i NPV, iz osnovnog softvera je u Whittle izvežen samo bakar, bez plemenitih metala. Zbog toga će i u zaključku biti prikazan samo ekonomski efekat na osnovu bakra, sa dugoročnom cenom od 6000 US\$/t katode, i to samo kao indikator trenda ekonomskih efekata.

U narednoj tabeli prikazana je planirana dugoročna dinamika otkopavanja po godinama iz Dopunskog rudarskog projekta otkopavanja i prerade rude bakra u ležištu "Veliki Krivelj" za kapacitet 10,6 × 106 tona vlažne rude godišnje, (IRM Bor, mart 2011. godine). 
Tabela 1. Projektovana dinamika otkopavanja DRP-om iz 2010. godine

\begin{tabular}{|c|c|c|c|c|c|c|}
\hline & & & & & Units to & Grade \\
\hline & tonne & tonne & Waste & Strip & process & input \\
\hline Period & in place & input & tonne & ratio & CU & CU \\
\hline 2011 & $29,001,893$ & $8,601,683$ & $20,400,210$ & 2.37 & 21416 & 0.00249 \\
\hline 2012 & $31,005,938$ & $10,601,750$ & $20,404,188$ & 1.92 & 33180 & 0.00313 \\
\hline 2013(1) & $30,992,084$ & $10,602,612$ & $20,389,472$ & 1.92 & 31618 & 0.00298 \\
\hline 2014(2) & $30,884,755$ & $10,604,019$ & $20,280,736$ & 1.91 & 24309 & 0.00229 \\
\hline 2015(3) & $31,005,202$ & $10,600,998$ & $20,404,204$ & 1.92 & 27239 & 0.00257 \\
\hline 2016(4) & $31,020,278$ & $10,601,968$ & $20,418,310$ & 1.93 & 31801 & 0.003 \\
\hline 2017 (5) & $31,010,886$ & $10,601,762$ & $20,409,124$ & 1.93 & 31242 & 0.00295 \\
\hline 2018(6) & $31,000,513$ & $10,600,062$ & $20,400,451$ & 1.92 & 33964 & 0.0032 \\
\hline 2019(7) & $27,399,915$ & $10,606,131$ & $16,793,784$ & 1.58 & 33518 & 0.00316 \\
\hline $2020(8)$ & $21,999,033$ & $10,600,785$ & $11,398,248$ & 1.08 & 32757 & 0.00309 \\
\hline $2021 / 2025$ & $91,604,842$ & $53,124,566$ & $38,480,276$ & 0.72 & 163712 & 0.00308 \\
\hline $2026 / 2031$ & $59,153,144$ & $55,451,108$ & $3,702,036$ & 0.07 & 207968 & 0.00375 \\
\hline Ukupno & $446,078,483$ & $212,597,444$ & $233,481,039$ & 1.10 & 672723 & 0.00316 \\
\hline
\end{tabular}

\subsection{Analiza dinamike otkopavanja u projektovanim fazama \\ (DRP 2011.) nakon izvedenih radova 2011 - Jul 2013.}

U softveru Whittle Fx, je projektovana dinamika otkopavanja u fazama 1, 2, 3 i 4, nakon pripreme podataka u osnovnom softveru (GEMCOM), tj. izvoza geološkog blok modela ležišta Veliki Krivelj sa odgovarajućom topografijom - stanjem radova 23. Jul 2013. godine (sl. 1.). Takođe je urađena i Pit Lista sa projektovanim fazama kopa i navedenim stanjem terena (sl. 2.). Ograničenja (limiti) u Whittle - u su pored geodetskog stanja rudarskih radova i količičina iskopa od 31.000.000 tona, računajući kao i u Projektu 10.6 Mt rude i

nešto više od 20 Mt jalovine sa kapacitetom transportnog sistema za jalovinu i odlaganjem na kamionskim odlagalištima Todorov Potok i Istočno odlagalište. Treći limit je godišnji kapacitet flotacijske prerade rude, sa graničnim sadržajem $\mathrm{Cu}$ u rudi, u ovom slučaju $0.15 \% \mathrm{Cu}$. Obzirom da je korišćeno stanje trena iz druge polovine jula 2013. godine, limiti za prvu godinu nove dinamike su uzeti srazmerno godišnjem kapacitetu ali za preostalih 5 meseci tekuće godine (iskop 12.916.666 t i ruda 4.375.000 t). 


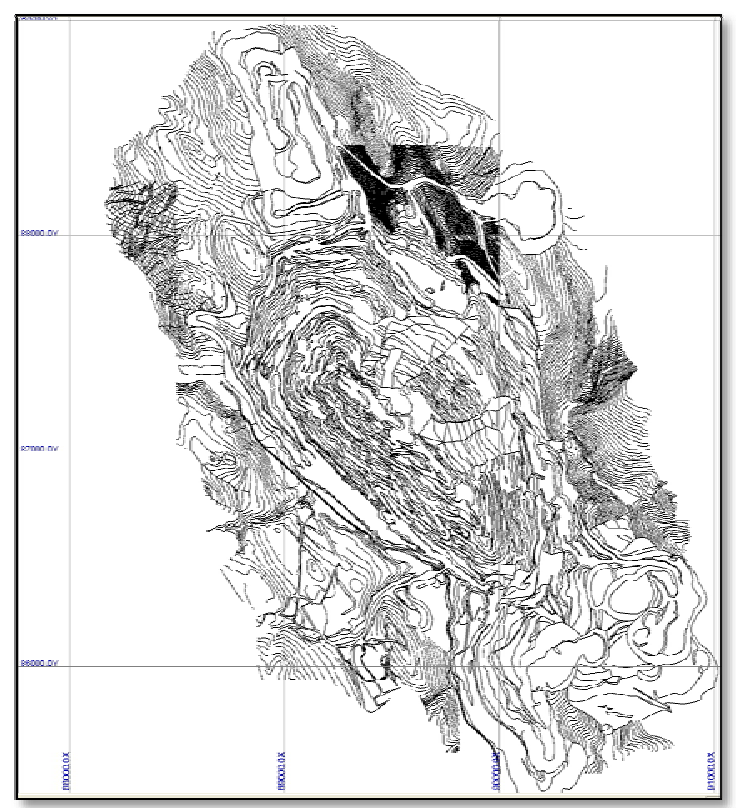

Sl. 1. Stanje rudarskih radova jula 2013. godine na pk. V. Krivelj
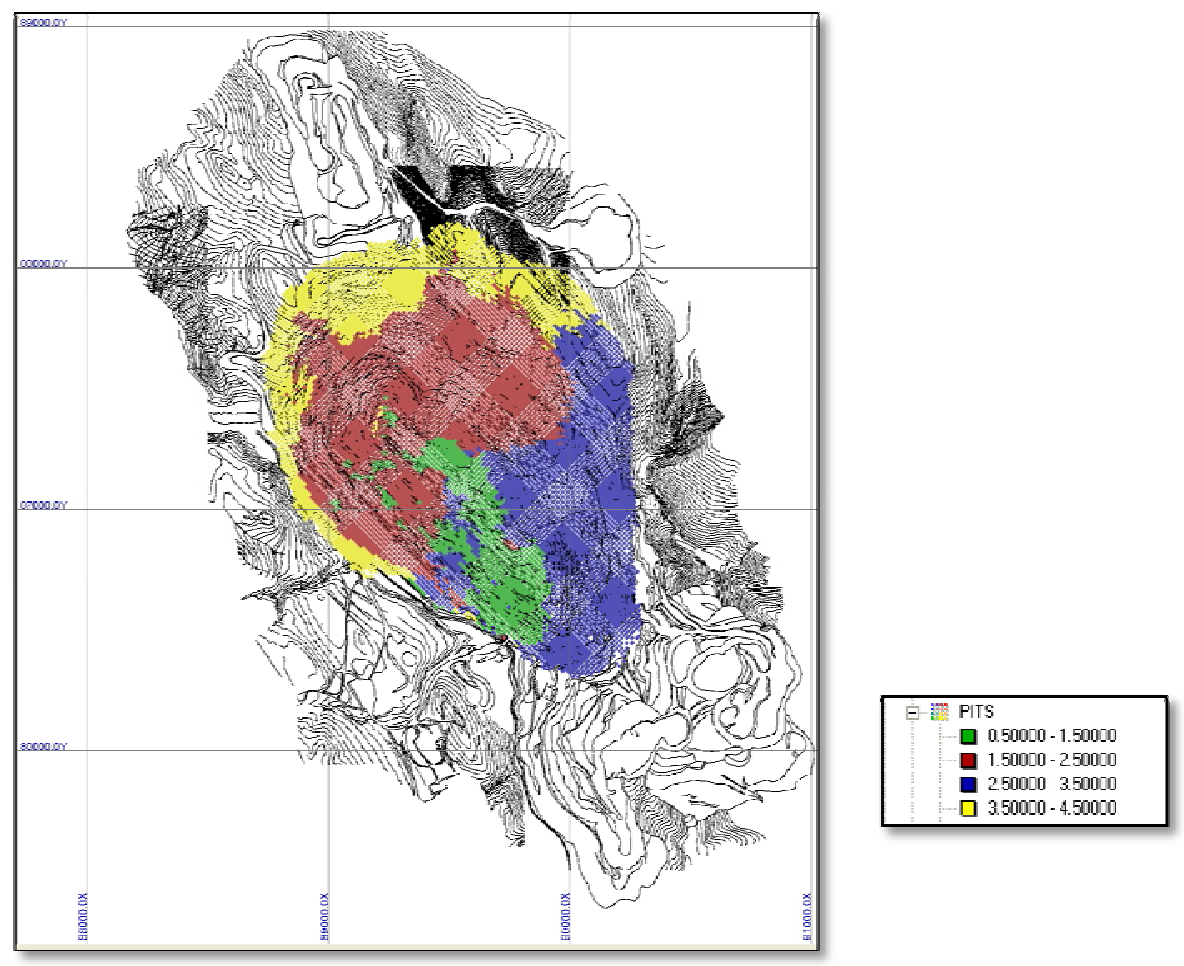

Sl. 2. Pit lista pk. V.Krivelj sa legendom faza 1 (0.5 - 1.5), faza 2 (1.5 - 2.5), $f$ aza $3(2.5-3.5)$, faza $4(3.5-4.5)$ 
Navedeni limiti su značajni zbog dinamike koja je generisana softverom, a prikazana u narednim tabelama (tabela 2 . zbirna dinamika i tabela 3. detaljna dinamika po fazama).

Tabela 2. Dinamika otkopavanja na osnovu analize sa stanjem radova 23.07.2013.godine

\begin{tabular}{|c|c|c|c|c|c|c|c|}
\hline & & & & & Units to & Grade & \\
\hline & tonne & tonne & Waste & Strip & process & input & \\
\hline Period & in place & input & tonne & ratio & $\mathrm{CU}$ & $\mathrm{CU}$ & \\
\hline $1(013)$ & $12,916,666$ & $4,733,404$ & $8,183,262$ & 1.73 & 14096 & 0.00298 & \\
\hline $2(014)$ & $31,000,000$ & $5,594,739$ & $25,405,261$ & 4.54 & 12553 & 0.00224 & \\
\hline $3(015)$ & $31,000,000$ & $10,595,226$ & $20,404,774$ & 1.93 & 24124 & 0.00228 & \\
\hline $4(016)$ & $31,000,000$ & $10,585,998$ & $20,414,002$ & 1.93 & 28117 & 0.00266 & \\
\hline $5(017)$ & $31,000,000$ & $10,595,816$ & $20,404,184$ & 1.93 & 32813 & 0.0031 & \\
\hline $6(018)$ & $31,000,000$ & $10,592,983$ & $20,407,017$ & 1.93 & 35140 & 0.00332 & \\
\hline $7(019)$ & $31,000,000$ & $10,598,912$ & $20,401,088$ & 1.92 & 37675 & 0.00355 & \\
\hline $8(020)$ & $31,000,000$ & $10,581,223$ & $20,418,777$ & 1.93 & 33399 & 0.00316 & \\
\hline $9(021)$ & $31,000,000$ & $10,599,457$ & $20,400,543$ & 1.92 & 25388 & 0.0024 & \\
\hline 10 & $28,084,404$ & $10,599,999$ & $17,484,404$ & 1.65 & 25644 & 0.00242 & LEGENDA \\
\hline 11 & $17,073,507$ & $10,600,000$ & $6,473,507$ & 0.61 & 29095 & 0.00274 & Bad \\
\hline 12 & $13,938,867$ & $10,600,000$ & $3,338,867$ & 0.31 & 30546 & 0.00288 & Good \\
\hline $13(025)$ & $12,145,076$ & $10,600,000$ & $1,545,076$ & 0.15 & 32578 & 0.00307 & P: 2021/2025 \\
\hline $14(026)$ & 11902505 & 10600000 & 1302505 & 0.12 & 34631 & 0.00327 & P: 2026/2031 \\
\hline 15 & 11202592 & 10600000 & 602592 & 0.06 & 35696 & 0.00337 & $\begin{array}{l}\text { PUSH -1 } \\
\text { PUSH - } 2\end{array}$ \\
\hline 16 & 11214552 & 10600000 & 614552 & 0.06 & 41155 & 0.00388 & PUSH -3 \\
\hline 17 & 10880675 & 10600000 & 280675 & 0.03 & 40006 & 0.00377 & PUSH - 4 \\
\hline 18 & 11179814 & 10600000 & 579814 & 0.05 & 43214 & 0.00408 & Total \\
\hline $19(031)$ & 5940727 & 5401306 & 539421 & 0.1 & 21067 & 0.0039 & \\
\hline Ulapno & $394,479,385$ & $185,279,063$ & $209,200,321$ & 1.13 & 576937 & 0.00311 & \\
\hline
\end{tabular}

U sledećoj tabeli data je detaljna dinamika otkopavanja po projektovanim fazama otkopavanja na kopu iz koje se vidi u kojim se periodima/godinama u kojoj fazi vrši otkopavanje.

Iz prikazanih tabela jasno je da se $\mathrm{u}$ 2014. godini ne ostvaruje Projektom planirana proizvodnja od 10,6 Mt $u$ projektovanim fazama (kolona 3, ,tonne input").
Rešenje će se opet, verovatno tražiti u ,pomeranju“ granica faza, odnosno ,skraćenju“ faza, o čemu je u uvodnom delu članka bilo reči. Skraćenje faza praktično znači brže napredovanje radova po dubini, ostavljajući pojedine delove faze (push back - a) neotkopanim, uglavnom delova gde je preovlađujuća jalovina ili nizak sadržaj metala u rudi. 
Tabela 3. Detaljna dinamika otkopavanja po fazama prema Analizi od 23.07.2013. godine

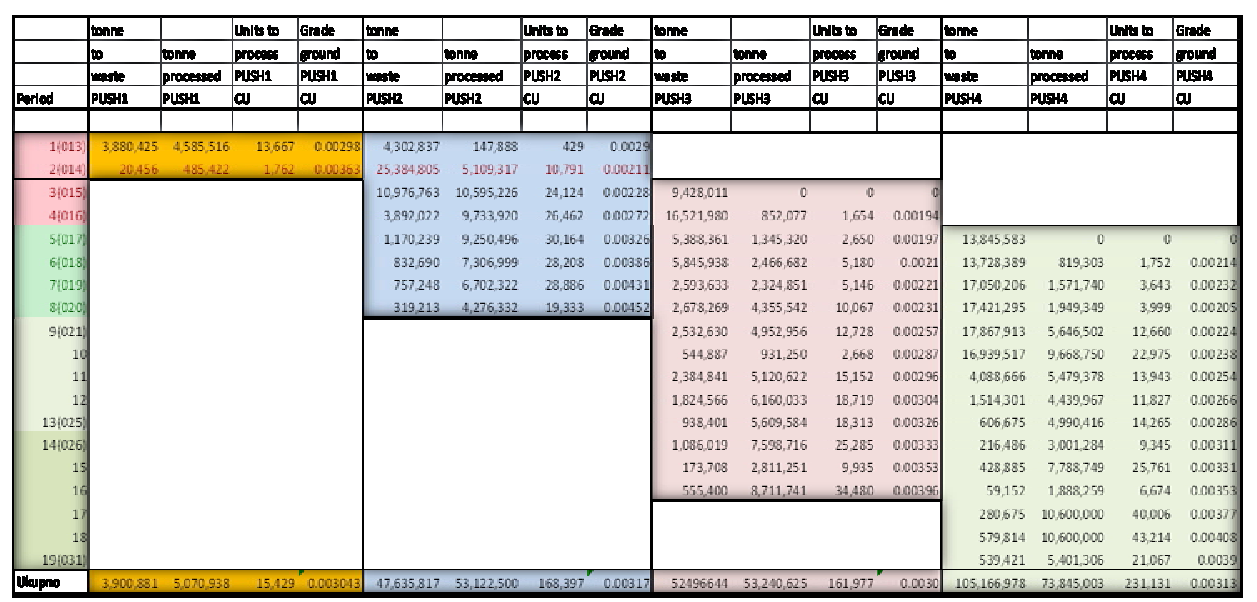

Grafički prikaz uporednih parametara određenih Projektom i parametara dobijenih
Analizom prikazani su u nastavku, i očigledno ilustruju razmatranu problematiku.

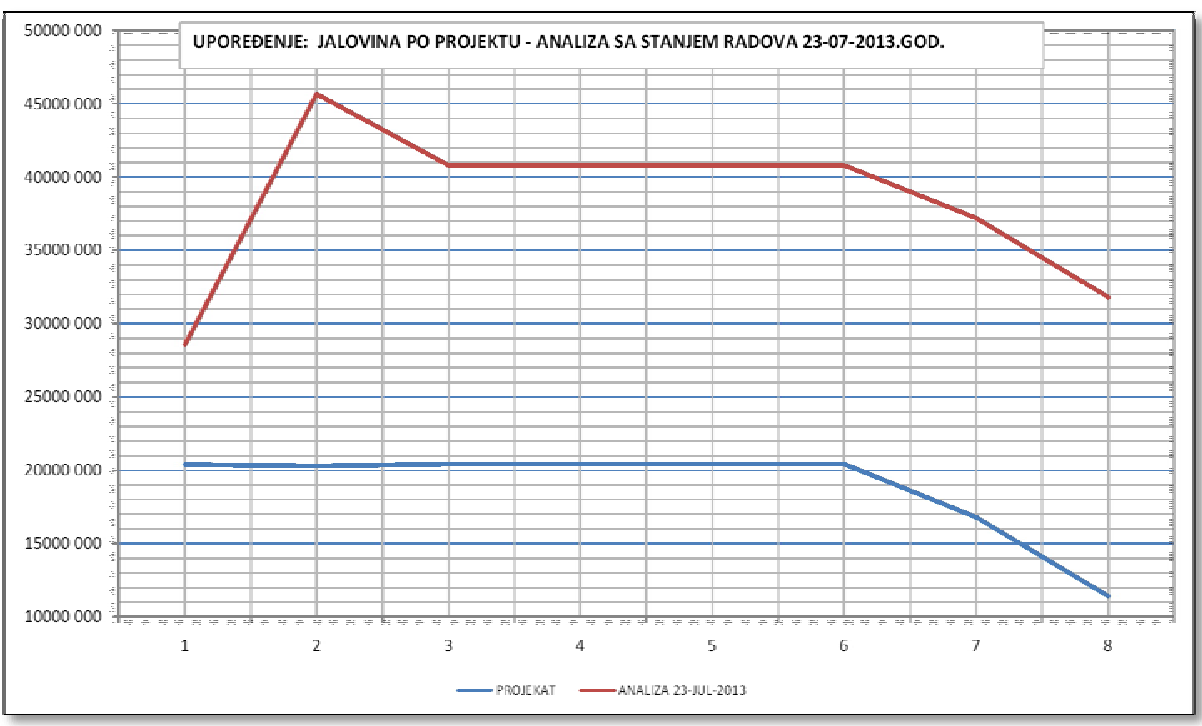

Grafik 1. Odnos količina JALOVINE po godinama u dinamici okopavanja prema Projektu $i$ generisanoj novoj dinamici u Analizi za period do 2020. god.

U 2013. godini kontinuitet u otkopavanju planiranih količina rude je uslovno zadržan (ili ga je moguće zadržati obzirom na vreme izrade Analize), samo zahvaljujući tome što se i u prethodnim godinama nisu ostvarivani godišnji planovi na otkopavanju rude, i time se delimično ublažio negativan efekat kašnjenja u raskrivanju. 


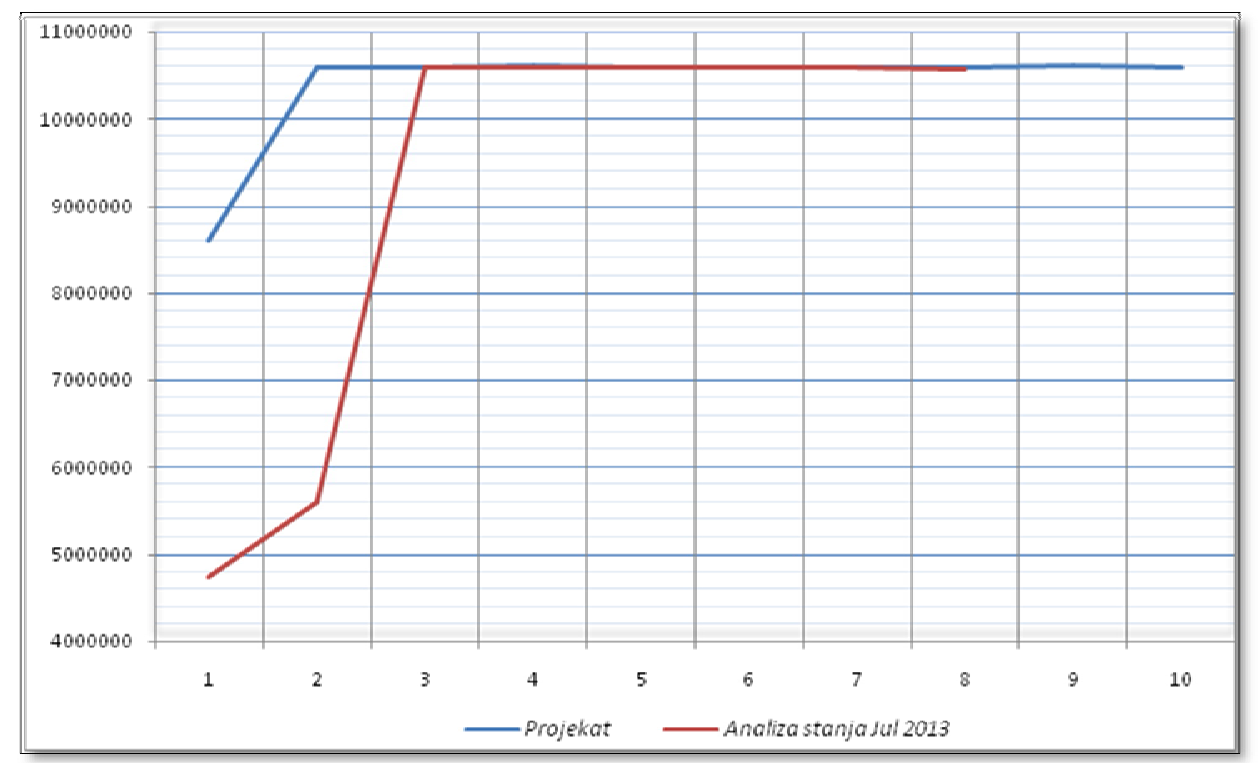

Grafik 2. Odnos RUDE u dinamici okopavanja prema Projektu i dinamici dobijenoj u Analizi za period do 2020. god.

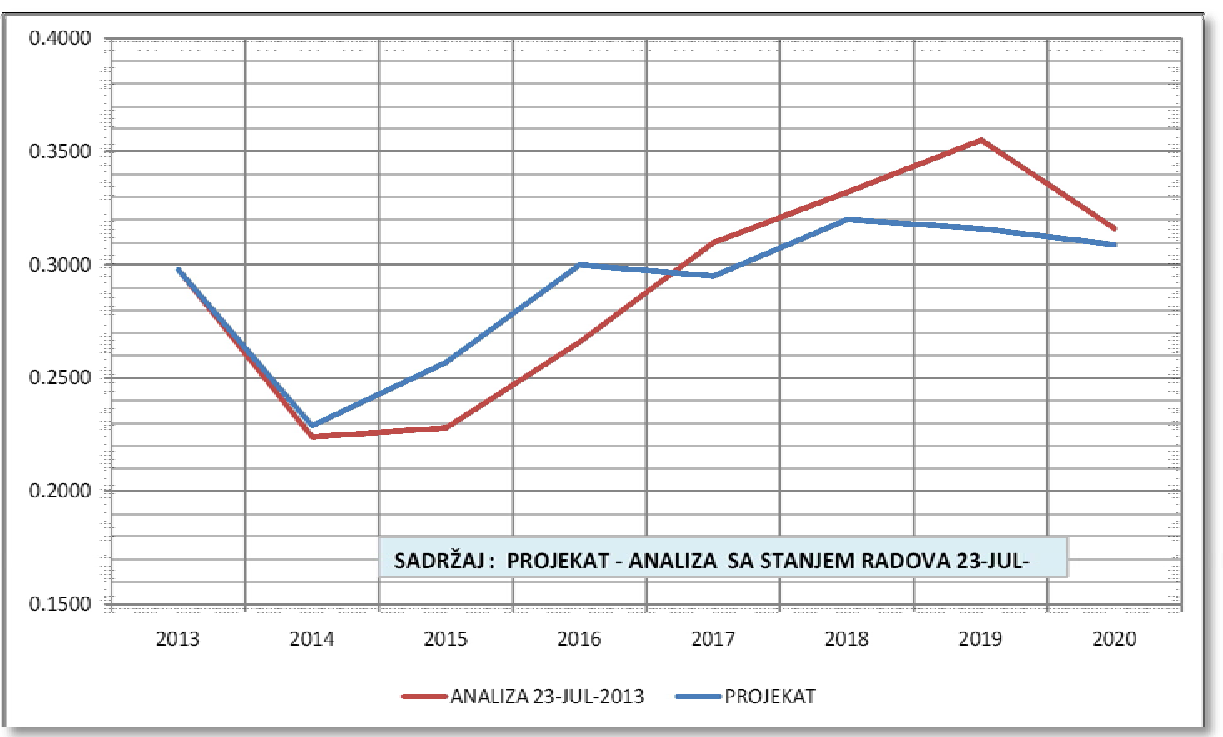

Grafik 3. Odnos SADRŽAJA u dinamici okopavanja prema Projektu i novoj dinamici u Analizi za period do 2020. godine 


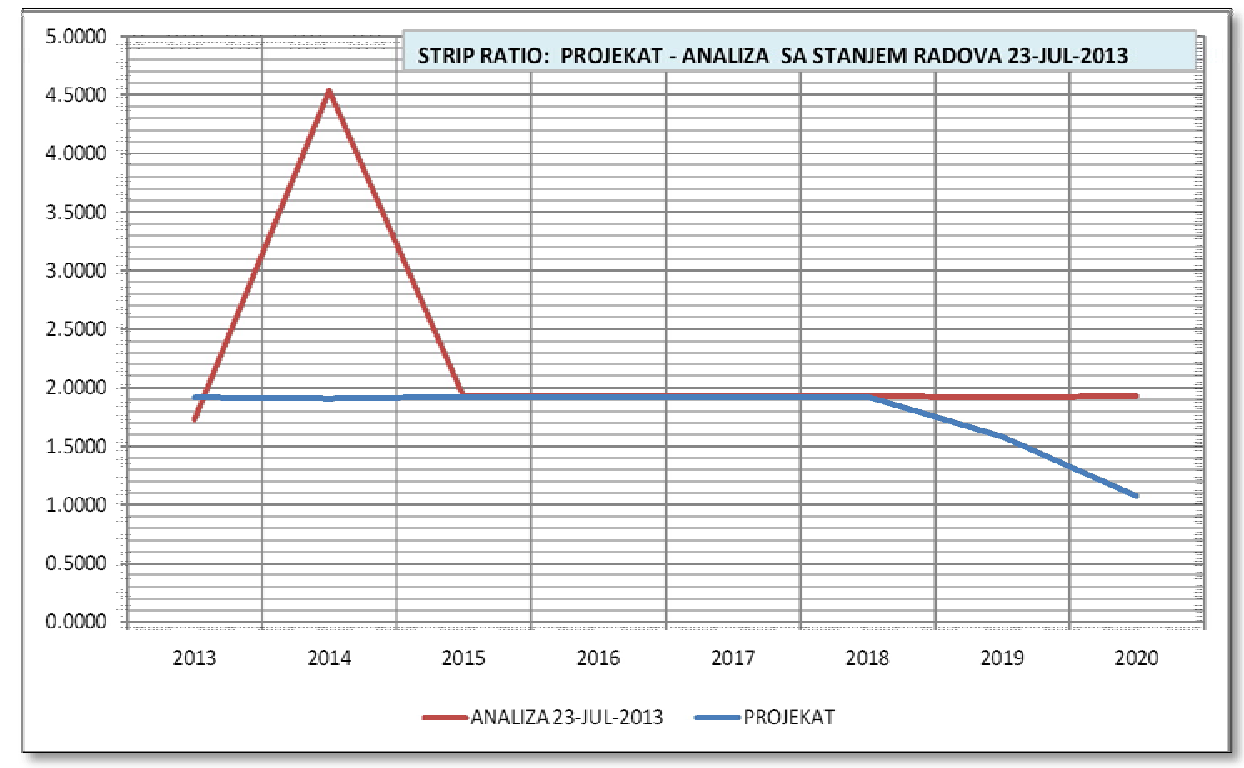

Grafik 4. Upoređenje KOEFICIJENTA RASKRIVKE ( $t$ jalovine /t rude) u projektu $i$ Analizi za period do 2020.godine

\section{ZAKLJUČAK}

Odstupanje od projektovanih rešenja u Projektu "Dopunski rudarski projekat otkopavanja i prerade rude bakra u ležištu "Veliki Krivelj" za kapacitet 10,6 × 106 tona vlažne rude godišnje, (IRM Bor, mart 2011. godine), nakon 2,5 godine rada po istom, a zbog kašnjenja na raskrivanju koje iznosi 24.280.718 t, dovodi do nužnog "skraćenja" projektovanih faza kopa sa ciljem održanja kontinuiteta u godišnjem kapacitetu otkopavanja rude od 10.6 Mt, kao izboru "manjeg zla od dva moguća".

Posledice takvog odstupanja su vidljive iz prikazanih tabela i grafika, kao i iz prethodnih razmatranja i one su:
- Smanjen srednji sadržaj bakra u rudi u narednom periodu od 3 godine -2014., 2015., 2016. godina (tabele i graficki prikaz broj 3.);

- U periodu 2014, 2015 i 2016. godina, povećan koeficijent raskrivke, odnodno neophodno je raditi sa povećanom količinom jalovine (tabela 2, grafik 4.);

- Iako primarni cilj nije bila detaljna ekonomska analiza, zbog čega nisu uzeti u obzir i plemeniti metali prilikom uvoza blok modela ležišta u Whittle, nameće se kao rezultat Analize $i$ pojava gubitka; samo po osnovu bakra (bez plemenitih metala) za cenu bakra od 6000 US\$/t, iznosi oko 26 Mil. US\$ (tabela 5., output Whittle Fx.): 
Tabela 5. Finansijski efekti (gubitak)

\begin{tabular}{|c|l|l|}
\hline & Open pit & Open pit \\
\hline & cashflow & cashflow \\
\hline Period & $\mathbf{\$}$ & $\mathbf{\$}$ disc \\
\hline & & \\
\hline $1(013)$ & $\mathbf{1 2 , 4 7 3 , 8 3 9}$ & $\mathbf{1 1 , 3 3 9 , 8 5 4}$ \\
$2(014)$ & $-26,956,603$ & $-22,278,185$ \\
\hline
\end{tabular}

- Zbog smanjenog sadržaja CU u rudi, javlja se $i$ mogućnost smanjenog flotacijskog iskorišćenja $i$ daljih negativnih uticaja u lancu prerade, do finalnog proizvoda katode. Takođe je sa smanjenim ulaznim sadržajem bakra u rudi do reda veličine od jedva preko $0.2 \%$ CU, smanjena i mogućnost ostvarenja planiranog sadržaja bakra u koncentratu u procesu flotiranja. Uticaji na ekonomske efekte trebali bi biti predmet analize tehnologa $u$ flotaciji i metalurga u topionici.

- Obzirom na investicije koje su zadnjih godina bile na kopu i u flotaciji, a još uvek traju u topionici, svetski trendovi u ovakvim slučajevima su da se poveća profit u prvim godinama nakon perioda investicionog ulaganja $i$ u što kraćem periodu povrati deo uloženog novca. Sto se kopa tiče, to se postiže na više načina. Jedan od načina je npr. $i$ optimizacijom graničnog sadržaja, zatim korišćenjem stok pajla (stock pile) i blendinga odgovarajućeg sadržaja, i sl. Na kopu Veliki Krivelj slučaj je obrnut. Nakon investiranih velikih sredstava, u početnim godinama nakon investiranja, (analizirani period), javlja se trend smanjenja profita.

- Vrlo je izvesno da će se takav trend nastaviti $i$ dalje ukoliko se nadoknadom jalovine radovi ne vrate $u$ projektovane konture kopa $i$ pod uslovom da u budućem periodu ne bude novih odstupanja od Projekta .

Sve napred navedeno govori $\mathrm{u}$ prilog tome da je ostvarivanje dinamike raskrivanja, iako je jalovina trošak, u površinskoj eksploataciji podjednako važno kao i proizvodnja rude. U podzemnoj eksploataciji je to faza pripreme - izrade rudarskih prostorija radi prilaza rudnom telu i stvaranja uslova za otkopavanje. Kašnjenje u raskrivanju poskupljuje ukupnu proizvodnju u narednom periodu i najčešće dovodi do gubljenja kontinuiteta $\mathrm{u}$ otkopavanju rude, ukoliko se u godišnje planove ne uključi i nadoknada zaostale jalovine, uz odgovarajuće uslove sa aspekta finansiranja dodatnih troškova. U suprotnom, to dalje implicira napred navedene posledice, a kao najgori slučaj - prekid kontinuiteta u otkopavanju rude $\mathrm{i}$ investiciono raskrivanje, a $\mathrm{u}$ celom tom periodu fiksni troškovi egzistiraju i ostaju nepromenjeni i pored toga što pojedini delovi pogona neće biti u funkciji (flotacija ili delovi flotacije), što kumuliranjem gubitaka može dovesti u pitanje dalju eksploataciju na kopu (rudniku). Ovakvim radom smanjuje se i vek eksploatacije rudni$\mathrm{ka}$, time vrednost rudnika (PV), odnosno NPV.

Takođe treba skrenuti pažnju i na pitanje da li će u budućnosti, ukoliko se nastavi opisani trend razvoja, uopšte 
postojati mogućnost u ležištu da se bilo kakvom optimizacijom nađe kontura kopa koja će biti ekonomski isplativa, bez perioda investicionog raskrivanja i sa isplativim vekom eksploatacije.

\section{LITERATURA}

[1] Dopunski rudarski projekat otkopavanja i prerade rude bakra u ležištu "Veliki Krivelj" za kapacitet 10,6 x $10^{6}$ tona vlažne rude godišnje, IRM Bor, marta 2011.godine;
[2] Optimization of Mining Engineering Design in Mineral Valuation - Wells, Howard M. - Technical Papers, Mining engineering, Vol. 30, No. 12, December 1978, pp. 1676-1684";

[3] Cut-off Grade Optimisation, Whittle Consulting Pty Ltd, Strategic Mine Planning Specialists;

[4] Planning Operating Cutoff Grades, Arnold R. Pasieka Consulting Mining Engineer Hatch Associates Ltd. Toronto, Ontario, George V. Sotirow Special Projects Engineer MAPAO North Bay, Ontario. 